
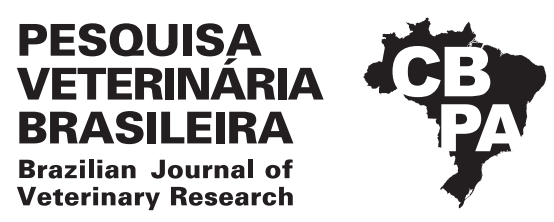

Pesq. Vet. Bras. 38(8):1664-1674, agosto 2018 DOI: $10.1590 / 1678-5150-P V B-4763$

Original Article

ISSN 0100-736X (Print)

ISSN 1678-5150 (Online)

\title{
Establishment of an experimental model of small intestinal ischemia and reperfusion injuries in New Zealand rabbits ${ }^{1}$
}

\author{
Alvaro P.L. Oliveira $^{2 *}$, Julia P.P. Rangel ${ }^{2}$, Luiz F.S. Riodades ${ }^{3}$, Bruna L. Almeida ${ }^{3}$, \\ Carlos Henrique T. Mathias ${ }^{4}$, Laura M.C. Conti ${ }^{2}$, Wagner A.B. Fiorio ${ }^{5}$ \\ and Betânia S. Monteiro ${ }^{6}$
}

\begin{abstract}
Oliveira A.P.L., Rangel J.P.P., Riodades L.F.S., Almeida B.L., Mathias C.H.T., Conti L.M.C., Fiorio W.A.B. \& Monteiro B.S. 2018. Establishment of an experimental model of small intestinal ischemia and reperfusion injuries in New Zealand rabbits. Pesquisa Veterinária Brasileira 38(8):1664-1674. Departamento de Medicina Veterinária, Universidade Vila Velha, Rua Comissário José Dantas de Melo 21, Vila Velha, ES 29102-920, Brazil. E-mail: oliveira.medvet@hotmail.com

The present study aimed to establish a methodology capable to cause intestinal ischemia and reperfusion injuries, to perform clamping of the jejunal segment of the extramural peri-intestinal marginal artery branch. For this, 37, 10-week-old male New Zealand breed rabbits were used. One rabbit was used to establish the anatomic references for the procedure and was not part of the six experimental groups; the rest were allocated into six experimental groups: Sham group, negative control, subjected only to midline celiotomy; group $\mathrm{I} 1 \mathrm{H}$ undergoing vascular occlusion for an hour; group I2H submitted to vascular occlusion for two hours; group I1H/R2H undergoing vascular occlusion for one hour followed by two hours of reperfusion; group I2H/R1H undergoing vascular occlusion for two hours, followed by reperfusion for one hour, and group I2H/R5H undergoing vascular occlusion for two hours followed by reperfusion for five hours. The rabbits were evaluated for the macroscopic aspects (color and peristalsis) of the jejunal segment, as well as the histological aspect, checking for presence or absence of mucosal destruction, edema, hemorrhaging, lymphatic vessel dilatation, and the presence of polymorphonuclear cells. It was observed that the macroscopic and histopathological lesions accentuated in larger employed ischemia and reperfusion times. Rabbits subjected to ischemia for two hours followed by reperfusion for five hours $(\mathrm{I} 2 \mathrm{H} / \mathrm{R} 5 \mathrm{H})$ made up the experimental group which was easily reproducible and showed moderate intestinal injury, different from the other groups.
\end{abstract}

INDEX TERMS: Experimental model, intestinal ischemia, reperfusion, injuries, New Zealand, rabbits, extramural peri-intestinal marginal artery, vascular clip, intestinal mucosa, intestinal submucosa, heterophil.

\footnotetext{
${ }^{1}$ Received on June 22, 2017.

Accepted for publication on July 23, 2017.

${ }^{2}$ Mestrado em Zootecnia, Laboratório de Células-tronco e Terapia Celular, Departamento de Medicina Veterinária, Universidade Vila Velha (UVV), Rua José Dantas de Melo 21, Vila Velha, ES 29102-920, Brazil. *Corresponding author: oliveira.medvet@hotmail.com

${ }^{3}$ Graduação em Medicina Veterinária, Bolsa de Iniciação Científica, Departamento de Medicina Veterinária, Universidade Vila Velha (UVV), Rua José Dantas de Melo 21, Vila Velha, ES 29102-920.

${ }^{4}$ Mestrado em Zootecnia, Laboratório de Células-tronco e Terapia Celular, Departamento de Medicina Veterinária, Universidade Vila Velha (UVV), Rua José Dantas de Melo 21, Vila Velha, ES 29102-920.

${ }^{5}$ Mestrado em Zootecnia, Departamento de Medicina Veterinária, Centro Avançado de Imagem e Patologia Veterinária, Universidade Vila Velha (UVV), Rua José Dantas de Melo 21, Vila Velha, ES 29102-920.

${ }^{6}$ Professor de Pós-Graduação em Zootecnia, Laboratório de Células-tronco e Terapia Celular, Departamento de Medicina Veterinária, Universidade Vila Velha (UVV), Rua José Dantas de Melo 21, Vila Velha, ES 29102-920.
}

\begin{abstract}
RESUMO.- [Estabelecimento de modelo experimental de indução da lesão de isquemia e reperfusão de intestino delgado em coelhos Nova Zelândia.] O presente estudo objetivou estabelecer uma metodologia capaz de causar lesões de isquemia e reperfusão intestinal, realizando clipagem de um ramo de artéria marginal peri-intestinal extramural em segmento jejunal. Para tal foram utilizados 37 coelhos da raça Nova Zelândia, machos, de 10 semanas de idade, alocados em seis grupos experimentais: grupo Sham, controle negativo, submetido apenas a celiotomia mediana; grupo $\mathrm{I} 1 \mathrm{H}$ submetido à oclusão vascular por uma hora; grupo $\mathrm{I} 2 \mathrm{H}$ submetido a oclusão vascular por duas horas; grupo I1H/R2H submetido a oclusão vascular por uma hora, seguida de reperfusão por duas horas; grupo I2H/R1H submetido a oclusão vascular
\end{abstract}


por duas horas, seguida de reperfusão por uma hora e grupo I2H/R5H submetido a oclusão vascular por duas horas seguida de reperfusão por cincos horas. Os animais foram avaliados quanto o aspecto macroscópico (coloração e peristaltismo) do segmento jejunal e quanto ao aspecto histopatológico, verificando presença ou ausência de destruição de mucosa, edema, hemorragia, dilatação de vasos linfáticos e presença de polimorfonucleares. Observou-se que as lesões macroscópicas e histopatológicas se acentuaram nos maiores tempos de isquemia e reperfusão empregados. Os animais submetidos à isquemia durante duas horas, seguida de reperfusão por cinco horas (I2H/R5H) compuseram o grupo experimental de fácil reprodução e foram os que apresentaram uma lesão intestinal moderada, diferentes dos demais grupos.

TERMOS DE INDEXAÇÃO: Modelo experimental, indução, lesão, isquemia, reperfusão, intestino delgado, coelhos, Nova Zelândia, artéria marginal peri-intestinal extramural, clipe vascular, mucosa intestinal, submucosa intestinal, heterófilo, jejuno.

\section{INTRODUCTION}

Intestinal ischemia occurs due to decrease or interruption of arterial and/or venous intestinal blood flow (hypoxia), causing damage to the mucosa. This event may occur due to acute or chronic obstruction of arteries and/or veins such as the celiac trunk, cranial mesenteric artery (CMA), the caudal mesenteric artery and/or corresponding vein, responsible for their irrigation (Carden \& Granger 2000, Ribeiro \& Yoshida 2005, Gonçalves et al. 2011).

Generally, after removal of the ischemic insult, a physiological process of intestinal reperfusion will occur, marked by a number of factors which will potentiate the ischemic injuries, increasing the initial inflammatory response, and may also cause a systemic reaction and multiple organ failure (Carden \& Granger 2000, Gao et al. 2006, Medeiros et al. 2013).

Due to the high mortality rate (60-80\%) caused by ischemia and reperfusion injuries (I/R) (Ritz et al. 2005, Boybeyi et al. 2014), several experimental studies are conducted in order to clarify the related pathophysiology and propose therapies for the correlated injuries, particularly with reperfusion.

Among the described experimental models, there are studies performed on rats, rabbits, dogs, cats, pigs and horses (Camargo et al. 2003, Kostopanagiotou et al. 2007, Avgerinos et al. 2010, Yurdakan et al. 2012, Freitas et al. 2017). According to Ribeiro \& Yoshida (2005), the most experimentally used test subjects are rodents, represented by about $73 \%$ of the studies, mainly for their ease to work with, adequateness to protocols, availability and low cost, as well as their anatomy being similar to humans. Still, among the most important species used are pigs (9\%), canines (8\%) and felines (6\%). In addition to animal species, other variability of the proposed models are time of ischemia, reperfusion time, intestinal segment submitted to injury, parameters used for evaluation, and idealized treatments (Zhao et al. 2003, Ribeiro \& Yoshida 2005, Gonzalez et al. 2015).

Experimental studies on I/R injuries can be defined by two dissimilar phases: the ischemic phase, in which there is a vessel occlusion, or occlusion of the feeding vessels, or decreased circulating blood flow, such as in controlled hypovolemic shock; and a phase called reperfusion, characterized by unblocking of the previously occluded vessel, or shock correction, in a way that the tissue perfusion becomes proper again (Carden
\& Granger 2000, Camargo et al. 2003, Ribeiro \& Yoshida 2005, Freitas et al. 2017).

Among the existing methods of ischemic induction arterial obstruction by vascular clamping can be highlighted as the most used followed by vascular stenosis vascular or extrinsic vascular compression; surgical tape with controlled blood flow release and induction of hypovolemic shock and hypothermia. This obstruction involves occlusion of the cranial mesenteric artery (CMA) (Ritz et al. 2005, Gao et al. 2006, Santos et al. 2008, Jiang et al. 2011, Ben et al. 2012, Boybeyi et al. 2014) or the CMA and cranial mesenteric vein (Guimarães et al. 2002, Tang et al. 2010) or the extramural peri-intestinal marginal artery (PIMA) (Guan et al. 2009). Some authors report that vascular clamping is the best method of ischemic applicability due to promoting the same occlusive situation in all animals and because of the similarity in clinical situations (Ribeiro \& Yoshida 2005, Freitas et al. 2009a, 2009b).

The objective of this study was to establish a methodology capable of causing ischemic and reperfusion injuries, by performing clamping of the extramural peri-intestinal marginal artery branch, and compare, through macroscopic and histological evaluations, structural abnormalities found in different ischemic and/or reperfusion times in intestinal segments, to establish an experimental model easily reproducible and which allows to infer a time of ischemia and reperfusion that entails a mild injury, yet compatible with the patient's life and with repair potential, in order to test future therapeutic protocols.

\section{MATERIALS AND METHODS}

Ethics statement. The study was conducted according to the standards of the Brazilian College of Animal Experimentation (COBEA) and was approved by the Ethics Committee, Bioethics and Animal Welfare (CEUA) of the University Vila Velha (UVV), process 294/2014

Experimental animals. For the study 37 New Zealand breed male rabbits were used, with ages of approximately 10 weeks, and average weight of $3.0 \mathrm{~kg}$, allocated in a modified container of 12 meters in length, lined with PVC and thermal insulation, with air conditioning and exhaust to control the temperature and electric timer keeping a photoperiod of 12/12 hours light and dark.

The animals were kept in individual cages, randomly distributed, and receiving water ad libtum and 100 grams/day of commercial rodent chow (Ração do Sítio Coelhão ${ }^{\circledR}$ - Guabi Nutrição Animal, Anápolis/G0).

Determination of the vascular segment to be clamped. To perform this step, one animal was used, which was submitted to premedication with Xylazine $(2.5 \mathrm{mg} / \mathrm{kg})$ associated with Ketamine $(25.0 \mathrm{mg} / \mathrm{kg})$ intramuscularly.

After sedation, the lateral auricular vein was catheterized, allowing administration of the anesthetic induction and euthanasia, using an anesthetic overdose of Thiopental sodium (50mg/kg/IV). Then, the jugular vein and carotid artery were dissected to allow bleeding and injection of white natural latex along with a blue liquid dye.

After finding the blue pigment in the abdominal and auricular region, the animal underwent extensive abdominal trichotomy, followed by pre-retro-umbilical medline celiotomy.

Was the location of the segment in an oral to aboral direction controlled, most proximal to the incision was identified, were the segments located in the same segment of bowel when considering distal jejunum, exteriorized from the cavity and observed for vascular organization originating from the cranial mesenteric artery and vein. After identification of the mesenteric artery and vein, a corresponding branch belonging to the extramural peri-intestinal marginal artery/vein 
irrigating an intestinal segment of approximately $8.0 \mathrm{~cm}$ was determined in order to standardize the clamping location (Fig.1).

After standardization, the surgical experimental phase was initiated.
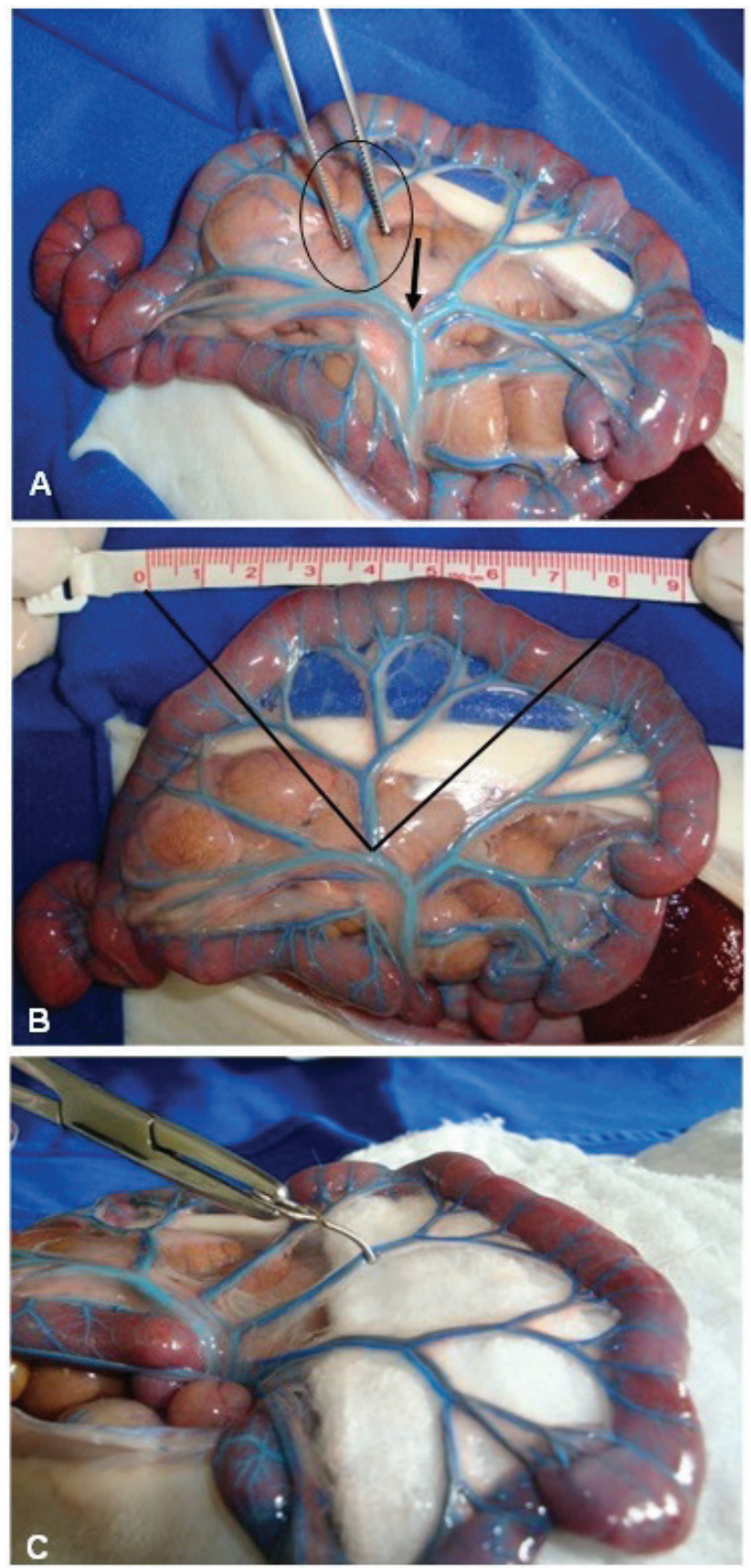

Fig.1. Evaluation of mesenteric irrigation in rabbit jejunum after completion of an injection technique using white natural latex together with a blue liquid dye. (A) Irrigation identification of the cranial mesenteric artery and vein (arrow) from the small intestine (jejunum) and the extramural peri-intestinal marginal artery/vein branch (circle), highlighting the dark blue color for the arterial branch and light blue for the venous branch. (B) Measurement of the irrigated area by the identified segment. (C) Clamping of the extramural peri-intestinal marginal artery and vein using a vascular clip.
Anesthetic procedures. The rabbits were kept on feed withdrawal for 8 hours. Prior to the surgery, pre-anesthetic drugs were administered associating Xylazine $(2.5 \mathrm{mg} / \mathrm{kg} / \mathrm{IM})$ and Ketamine $(25 \mathrm{mg} / \mathrm{kg} / \mathrm{IM})$. The marginal auricular vein was cannulated for the establishment of fluid therapy and implementation of analgesia with Tramadol hydrochloride $(1.0 \mathrm{mg} / \mathrm{kg} / \mathrm{IV})$. After the loss of both eyelid and laryngotracheal reflexes, tracheal intubation was performed to allow the maintenance of anesthesia by dose effective inhalation of isoflurane. The central auricular artery was catheterized.

The patient was placed in a supine position, propped up on surgical chute and submitted to a broad trichotomy of the abdominal region.

Surgical procedure. The surgical field was prepared by performing antisepsis with $70 \%$ alcohol and $2 \%$ topical chlorhexidine topical, and the surgical drapes were positioned. Pre-retro-umbilical midline celiotomy was performed measuring approximately $6.0 \mathrm{~cm}$ in a cranial-caudal direction. Was the location of the segment in an oral to aboral direction controlled, most proximal to the incision was identified, were the segments located in the same segment of bowel when considering distal jejunum and the intestinal segment of the jejunum, most proximal to the incision, was identified and exteriorized from the cavity and the extramural peri-intestinal marginal artery/vein branch and occlusion performed using a vascular clip (Fig.2).

The occlusion time varied according to the experimental group. During the occlusion time interval, the animals remained anesthetized and had their abdominal cavity sutured by separate stitches, to prevent loss of abdominal fluid, and contamination. No mensuration which allowed proof of absence and return of blood flow was performed. Still collateral blood flow was maintained. After removal of the vascular clip, muscle fascia was approximated with the Sultan suture $(\mathrm{X})$ using Nylon 1, the subcutaneous tissue with simple continuous suture using Vicryl 0 , and the skin was approximated by intradermal suturing using Nylon 0 .

Experimental groups. The animals were numbered from 1 to 36 , and were distributed randomly into the experimental groups containing six animals (Table 1 ). The order of the surgeries obeyed the pre-established numbers. The ischemia and/or reperfusion duration was established and adapted from models proposed by Gao et al. (2006), Jiang et al. (2011), and Barriga et al. (2013). During the entire ischemia and/or reperfusion duration, the intestinal segment was maintained within the abdominal cavity.

Sham group (Sham): Patients underwent pre-retro-umbilical midline celiotomy and manipulation of the jejunum segment, without performing occlusion of vessels. The animals remained anesthetized for two hours, after this time period intestinal fragments were

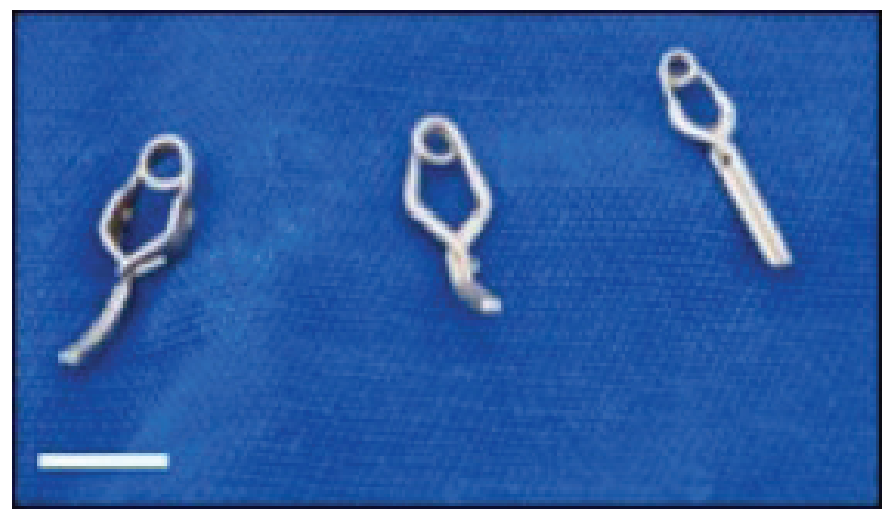

Fig.2. Vascular clips used during pre-retro-umbilical midline celiotomy in New Zealand rabbits, to promote extramural peri-intestinal marginal blood flow obstruction. (Scale $=1 \mathrm{~cm}$ ). 
Table 1. Summary/proposed design for preparation of the experimental groups

\begin{tabular}{cccc}
\hline Group & Number of animals & Ischemia/Reperfusion duration & Euthanasia (moment/time) \\
\hline Sham & 6 & - & 1h after beginning celiotomy \\
I1H & 6 & 1 hour & Following procedure conclusion \\
I2H & 6 & 2 hours & Following procedure conclusion \\
I1H/R2H & 6 & 1 hour / 2 hours & Animal awake, anesthetized once again, after 2 hours of reperfusion \\
I2H/R1H & 6 & 2 hours / 1 hour & Animal awake, anesthetized once again, after 1 hour of reperfusion \\
I2H/R5H & 6 & 2 hours / 5 hours & Animal awake, anesthetized once again, after 5 hours of reperfusion
\end{tabular}

collected for performance of exams, and euthanasia of the animals by anesthetic overdose was performed.

One-hour ischemia (I) group (I1H): Patients underwent pre-retro-umbilical midline celiotomy and manipulation of the jejunum segment, followed by realization of vessel occlusion for 1 hour. The animals remained anesthetized for an hour, after this time period intestinal fragments were collected for performance of exams, and euthanasia of the animals by anesthetic overdose was performed.

Two-hour ischemia (I) group (I2H): Patients underwent pre-retro-umbilical midline celiotomy and manipulation of the jejunum segment, followed by realization of vessel occlusion for 2 hours. The animals remained anesthetized for two hours, after this time period intestinal fragments were collected for performance of exams, and euthanasia of the animals by anesthetic overdose was performed.

One-hour ischemia/two-hour reperfusion group (I1H/R2H): Patients underwent pre-retro-umbilical midline celiotomy and manipulation of the jejunum segment, followed by realization of vessel occlusion for 1 hour. The animals remained anesthetized for one hour and after this time the vascular clip was removed, and suture in the mesentery near the clamping site was performed using a 4-0 blue polypropylene suture. Anesthesia was ceased, and the patient was taken to the anesthetic recovery location, remaining alive for two hours. After that time, they were anesthetized and operated on once again, intestinal fragments were collected for performance of exams, and euthanasia of the animals by anesthetic overdose was performed.

Two-hour ischemia/one-hour reperfusion group (I2H/R1H): Patients underwent pre-retro-umbilical midline celiotomy and manipulation of the jejunum segment, followed by realization of vessel occlusion for 2 hours. The animals remained anesthetized for two hours and after this time the vascular clip was removed, and suture in the mesentery near the clamping site was performed using a 4-0 blue polypropylene suture. Anesthesia was ceased, and the patient was taken to the anesthetic recovery location, remaining alive for one hour. After that time, they were anesthetized and operated on once again, intestinal fragments were collected for performance of exams, and euthanasia of the animals by anesthetic overdose was performed.

Two-hour ischemia/five-hour reperfusion group (I2H/R5H): Patients underwent pre-retro-umbilical midline celiotomy and manipulation of the jejunum segment, followed by realization of vessel occlusion for 2 hours. The animals remained anesthetized for two hours and after this time the vascular clip was removed, and suture in the mesentery near the clamping site was performed using a 4-0 blue polypropylene suture. Anesthesia was ceased, and the patient was taken to the anesthetic recovery location, remaining alive for five hours. After that time, they were anesthetized and operated on once again, intestinal fragments were collected for performance of exams, and euthanasia of the animals by anesthetic overdose was performed.
Trans-surgical macroscopic evaluation. Before and after clamping of the extramural peri-intestinal marginal artery/vein, the macroscopic aspect of the segment irrigated by the occluded branch and adjacent segments was evaluated regarding color, and peristalsis ("pinch test"). Macroscopic findings were compared between animals of the same group, as well as between groups.

Histopathological examination. Intestinal fragments of the jejunum were collected, of approximately $0.5 \mathrm{~cm}$ in extension, tubular shaped and wrapped in gauze, from the central region affected by the previously marked ischemic injury through a suture stitch using 4-0 polypropylene. Samples were collected with aid of a scalpel blade, and with every animal the blade was exchanged for a new one. After the collection, the animals were euthanized.

All the extracted fragments were fixed in $10 \%$ formalin and embedded in paraffin. Tissues were sectioned in cuts at approximately 4-5 $\mu \mathrm{m}$ for confection of histological slides, and stained with hematoxylin and eosin.

Histologically, at least six randomly chosen fields based on Jiang et al. (2011), were evaluated per slide for each animal as well as for each segment, and the median of the events considered in order to classify the injuries into scores. The evaluator was unaware of the evaluated groups. The evaluations were conducted with 10x and 40x objectives.

The histopathological classification of the injuries from the ischemic fragment was established according to an adaptation of the score proposed by Chiu et al. (1970) (0- Unaltered mucosa; 1- Villi preserved without cell lysis, without inflammatory process (IP), and with subepithelial spaces (SE); 2 - Cell lysis, with SE, increased spacing between the villi; 3-Villi denudation with inflammatory cells (IC), dilated capillaries; 4- Structural destruction of the villi, with IC, basal glandular necrosis and ulceration; 5- Total destruction of the mucosa), as well as an adaptation of Pagliosa et al. (2009) for edema, hemorrhage, presence of polymorphonuclear cells (0-Absent; 1- Incipient; 2- Light; 3- Moderate; 4- Intense) and lymphatic dilatation ( 0 - Absent; 1 - Moderate; 2 - Intense). To evaluate the presence of a mononuclear inflammatory process, a score was established (0- Absent; 1- Incipient; 2- Light; 3- Moderate; 4- Intense). Descriptive analysis of the lesions found in each group was also conducted.

Statistical analysis. The Kolmogorov-Smirnov test was used to test the normality of the histopathological data classified in scores. Then, the data was evaluated using the nonparametric Kruskal-Wallis test, followed by Dunn's post-test, and considered significant when $\mathrm{p}<0.05$. Data was analyzed using the GraphPadPrism $5^{\circledR}$ program, to evaluate inflammation in the proposed time for each group on the histopathological characteristics of the intestinal fragments.

\section{RESULTS}

The anesthetic induction procedure was performed in order not to cause excitement of the animals so that the hemodynamic and respiratory functions remain stable until 
the time of the procedure. In some animals, intubation could not be performed, so these were kept with the aid of a mask. No anesthetic complications were observed.

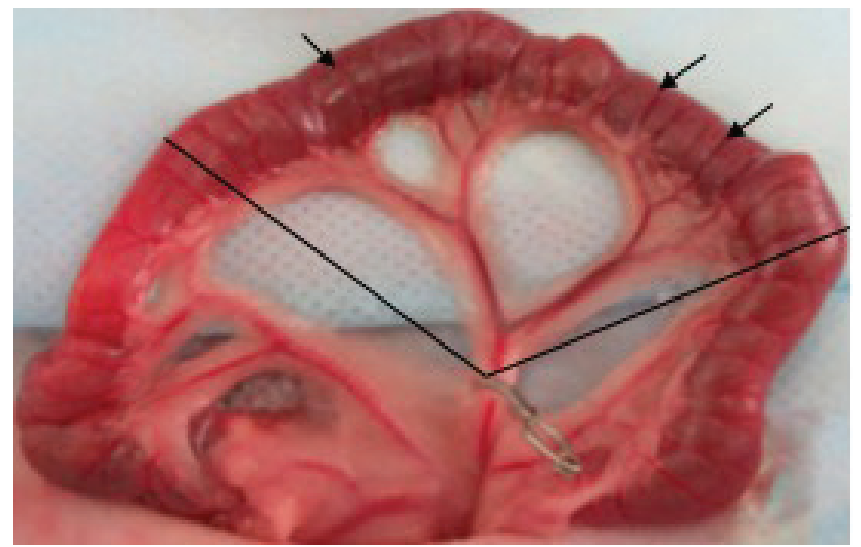

Fig.3. Jejunum segment subjected to occlusion of the extramural peri-intestinal marginal artery/vein belonging to a rabbit allocated in the group submitted to two hours of ischemia (I2H). Highlighting the intestinal region irrigated by the occluded vascular branch, redder serous, with hyperemic blood vessels.
In animals placed in the Sham group, only undergoing celiotomy, it was observed after one hour of anesthesia that all the animals had pink colored intestinal serous, without alterations, occurring only a little hemorrhaging at the moment of the intestinal fragment collection, which was considered normal.

The clamping of the extramural peri-intestinal marginal artery/vein, allowed occlusion of blood flow to a segment of approximately $8 \mathrm{~cm}$ in length, providing after two hours, discoloration of the intestinal serosa, and therefore suggesting congestion and hypomotility. The adjacent regions $(10 \mathrm{~cm}$ cranial and $10 \mathrm{~cm}$ caudal $)$ to the irrigated portion, presented slightly changed. The $\mathrm{I} 2 \mathrm{H}$ group showed a more reddish serous with blood vessel more apparent, congested and hyperemic than observed in the I1H group (Fig.3).

In the groups submitted to reperfusion, macroscopic alterations after removal of the vascular clip was similar to that observed in the $\mathrm{I} 1 \mathrm{H}$ and $\mathrm{I} 2 \mathrm{H}$ groups.

However, in the I1H/R2H group, minutes after clearing the obstruction, it was observed that the hyperemia had reduced, returning to an almost normal aspect.

When celiotomy was performed again after reperfusion, there was decreased response to the "pinch" test, suggesting intestinal hypomotility, and excessive bleeding at the time of fragment collection. In the I2H/R 5H group a paler serous, with increased thickness and shiny aspect was noted, suggesting edema (Fig.4).
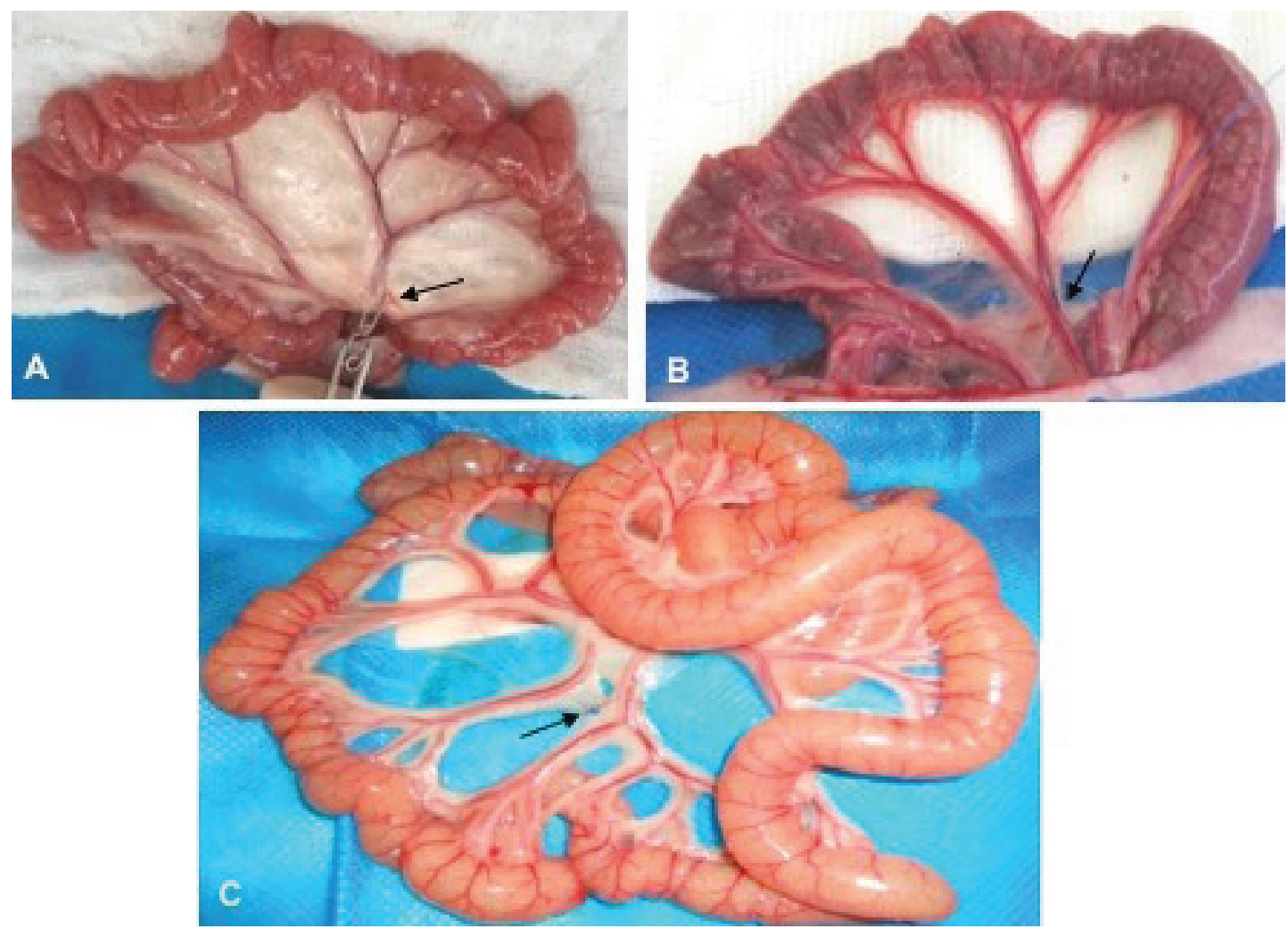

Fig.4. Jejunum segment of a rabbit allocated in the group submitted to two hours of ischemia and five hours of reperfusion (I2H/R5H). (A) Normal intestinal aspect, with pink serosa immediately before the occlusion of the extramural peri-intestinal marginal artery/vein using a vascular clip (arrow). (B) Intestine with ischemic serosa, congested extramural vessels immediately after removal of vascular clip, and mesentery suturing using a blue non-absorbable wire to mark the ischemic site (arrow). (C) Intestine displaying a paler serous, with increased thickness and shiny aspect as well as hyperemic extramural vessels, suggesting edema, five hours after reperfusion. Highlighting (arrow) the mesentery suture indicating blood vessel occlusion site. 
The regions adjacent to the injury site had a redder serosal aspect and presence of blood vessels a little more apparent.

Histologically, considering the intestinal mucosal injuries, it was observed that the longer the reperfusion time, the more frequent presence of villus denudation with inflammatory cells (IC), dilated capillaries (score 3), however, in none of the experimental groups was complete destruction of the mucosa noted.

Statistically, the groups I1H/R2H, I2H/R1H, and I2H/R5H showed significant difference compared to the Sham group (Fig.5); and groups I2H/R1H and I2H/R5H (Fig.6) showed a significant difference to the $\mathrm{I} 1 \mathrm{H}$ group. The other alterations are presented in Table 2 .

Regarding the mucosa erosion, majority of the samples observed showed absence of erosion (score 0 ) and with some animals from the groups submitted to reperfusion showing separation between the epithelium and lamina propria in the villus tip (score 1 ).

For the variable mucosal edema evaluated, the IH1/R2H, $\mathrm{I} 2 \mathrm{H} / \mathrm{R} 1 \mathrm{H}$ and $\mathrm{I} 2 \mathrm{H} / \mathrm{R} 5 \mathrm{H}$ groups showed mild classification standard (score 2) and were significantly different compared to the Sham group. Still, the I2H/R5H group also showed difference compared to the $\mathrm{I} 1 \mathrm{H}$ group. The alterations are shown in Table 3.

Considering the variable hemorrhage in mucosa, most observations were graded a score of 0 , that is, absent, with rare incipient hemorrhage findings (score 1). There was no statistical difference between the groups. The findings are shown in Table 4.

As for the presence of polymorphonuclear infiltrate, most often mild (score 2) to moderate (score 3) degrees were observed, especially in groups that underwent reperfusion. There was statistical difference in I1H/R2H, I2H/R1H, and $\mathrm{I} 2 \mathrm{H} / \mathrm{R} 5 \mathrm{H}$ groups compared to the Sham group. There was also difference in the $\mathrm{I} 2 \mathrm{H} / \mathrm{R} 5 \mathrm{H}$ group compared to the I1H group ( $\mathrm{p}<0.05)$. Other alterations are presented in Table 5.

For the variable mucosa lymphatic dilatation, in the reperfusion groups intense dilation was observed (score 2)

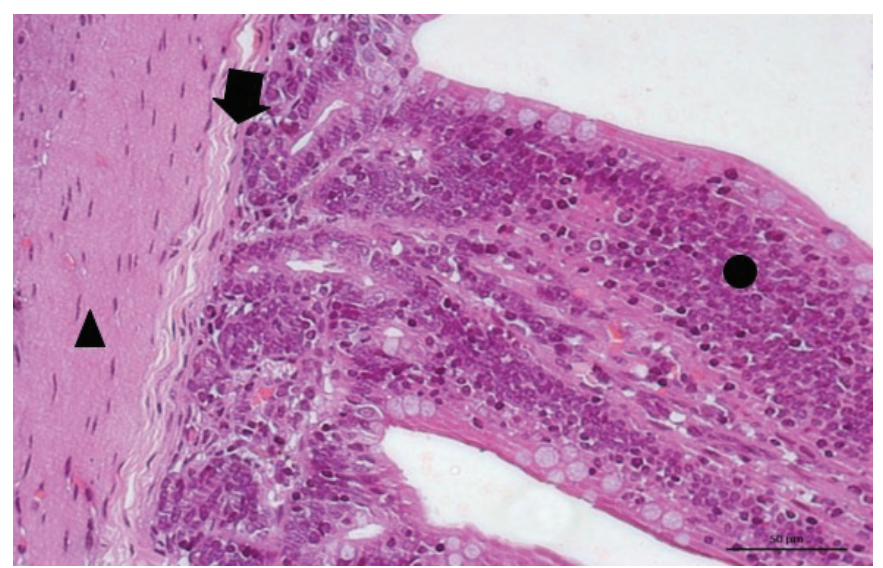

Fig.5. Photomicrography of a rabbit allocated in the Sham group exhibiting normal histopathological aspects of mucosa (circle), submucosa (arrow), and muscle (triangle) layers of the intestinal segment. HE, 40x.
(Fig.7), especially when compared with absent (score 0) and moderate degrees (score 1 ) present in the animals of the Sham and $\mathrm{I} 1 \mathrm{H}$ group. The $\mathrm{I} 2 \mathrm{H}$ group was significantly different from the Sham group $(\mathrm{p}<0.01)$. The groups I2H/R1H and I2H/R5H had significant difference from the Sham group. The other alterations are presented in Table 6.

Presence of mononuclear inflammatory process was not observed in any histological section. In addition to the variables evaluated, during histological evaluation I1H/R2H, I2H/R1H, and $\mathrm{I} 2 \mathrm{H} / \mathrm{R} 5 \mathrm{H}$ groups showed the presence of shortened villi size compared to the Sham group.

Submucosa histopathological showed edema present in moderate (score 3) to intense levels (score 4) consequent to the increase of ischemia and/or reperfusion duration. The I1H/R2H, I2H/R1H, and I2H/R5H groups were significantly different compared to the Sham group. There were also differences between the groups I2H/R1H and I2H/R5H compared to the $\mathrm{I} 1 \mathrm{H}$ group $(\mathrm{p}<0.05, \mathrm{p}<0.01)$. The other alterations are presented in Table 7.

For submucosal hemorrhage the I2H/R5H group was significantly different from the other study groups $(\mathrm{p}<0.05)$, for it was the only one in which incipient hemorrhage was observed (score 1). In the other groups, hemorrhage in the submucosa was absent.

The presence of polymorphonuclear cell infiltration (PMN) in the submucosa was similar to the data evidenced in the mucosa, where longer ischemia and reperfusion times resulted in moderate degrees (score 3) of PMN. There was a significant difference between the groups $\mathrm{I} 1 \mathrm{H} / \mathrm{R} 2 \mathrm{H}$, $\mathrm{I} 2 \mathrm{H} / \mathrm{R} 1 \mathrm{H}$, and $\mathrm{I} 2 \mathrm{H} / \mathrm{R} 5 \mathrm{H}$ compared to the Sham group. There were also significant differences between the groups $\mathrm{I} 2 \mathrm{H} / \mathrm{R} 1 \mathrm{H}$ and $\mathrm{I} 2 \mathrm{H} / \mathrm{R} 5 \mathrm{H}$ compared to the group $\mathrm{I} 1 \mathrm{H}$. The other alterations are presented in Table 8.

Regarding dilatation of lymphatic vessels in submucosa it was also evidenced that the longer ischemia and reperfusion times implicated in minor degrees (score 2) of dilation (Fig.8). There was a significant difference between the groups

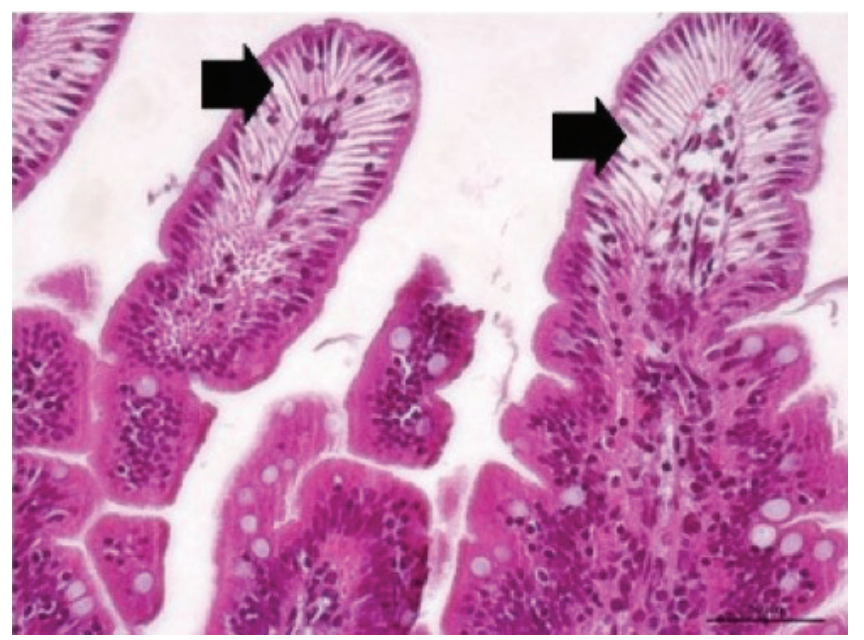

Fig.6. Photomicrography of a rabbit allocated in the I2H/R5H group exhibiting formation of sub epithelial space in the apical region of the intestinal segment's mucosa. HE, 20x. 
Table 2. Results, in score, of the histological analysis for injury in jejunum mucosa belonging to New Zealand rabbits submitted to ischemia and reperfusion by clamping of the extramural peri-intestinal marginal artery/vein

\begin{tabular}{|c|c|c|c|c|c|c|}
\hline \multirow{2}{*}{ Rabbits } & \multicolumn{6}{|c|}{ Score for mucosa injury } \\
\hline & Sham & $\mathrm{I} 1 \mathrm{H}$ & $\mathrm{I} 2 \mathrm{H}$ & $\mathrm{I} 1 \mathrm{H} / \mathrm{R} 2 \mathrm{H}$ & $\mathrm{I} 2 \mathrm{H} / \mathrm{R} 1 \mathrm{H}$ & $\mathrm{I} 2 \mathrm{H} / \mathrm{R} 5 \mathrm{H}$ \\
\hline 1 & 0 & 1 & 1 & 2 & 2 & 3 \\
\hline 2 & 0 & 1 & 1 & 2 & 2 & 3 \\
\hline 3 & 0 & 1 & 1 & 2 & 2 & 3 \\
\hline 4 & 0 & 1 & 1 & 1 & 2 & 3 \\
\hline 5 & 0 & 1 & 1 & 2 & 2 & 3 \\
\hline
\end{tabular}

In the same line, identical letters represent statistical equivalence and different letters represent differences between the groups. Chiu et al. (1970), adapted.

Table 3. Results, in score, of the histological analysis of mucosa edema in the jejunum mucosa belonging to New Zealand rabbits subjected to ischemia and reperfusion by clamping of the extramural peri-intestinal marginal artery/vein

\begin{tabular}{ccccccc}
\hline \multirow{2}{*}{ Rabbits } & \multicolumn{5}{c}{ Score for edema in mucosa } \\
\cline { 2 - 6 } & SHAM & I1H & I2H & I1H/R2H & I2H/R1H & I2H/R5H \\
\hline 1 & 0 & 0 & 2 & 2 & 2 & 2 \\
2 & 0 & 0 & 1 & 2 & 2 & 2 \\
3 & 0 & 1 & 0 & 1 & 2 & 2 \\
4 & 0 & 1 & 1 & 2 & 2 \\
5 & 0 & 0 & 2 & 2 & 2 \\
6 & 0 & 1 & $2^{\text {bc }}$ & $2^{\text {bc }}$ & 2 \\
Median & $0^{\text {abc }}$ & $0,5^{\text {ac }}$ & 1 & $2^{\text {b }}$
\end{tabular}

In the same line, identical letters represent statistical equivalence and different letters represent differences between the groups.

Table 4. Results, in score, of the histological analysis of mucosa hemorrhage in the jejunum mucosa belonging to New Zealand rabbits subjected to ischemia and reperfusion by clamping of the extramural peri-intestinal marginal artery/vein

\begin{tabular}{|c|c|c|c|c|c|c|}
\hline \multirow{2}{*}{ Rabbits } & \multicolumn{6}{|c|}{ Score for hemorrhage in mucosa } \\
\hline & Sham & $\mathrm{I} 1 \mathrm{H}$ & $\mathrm{I} 2 \mathrm{H}$ & $\mathrm{I} 1 \mathrm{H} / \mathrm{R} 2 \mathrm{H}$ & $\mathrm{I} 2 \mathrm{H} / \mathrm{R} 1 \mathrm{H}$ & $\mathrm{I} 2 \mathrm{H} / \mathrm{R} 5 \mathrm{H}$ \\
\hline 1 & 0 & 0 & 0 & 0 & 1 & 1 \\
\hline 2 & 0 & 0 & 0 & 1 & 1 & 2 \\
\hline 3 & 0 & 0 & 0 & 0 & 0 & 0 \\
\hline 4 & 0 & 0 & 0 & 0 & 0 & 1 \\
\hline 5 & 0 & 0 & 0 & 1 & 0 & 1 \\
\hline
\end{tabular}

In the same line, identical letters represent statistical equivalence and different letters represent differences between the groups.

Table 5. Results, in score, of the histological analysis for presence of polymorphonuclear cell infiltration (PMN) in the jejunum mucosa belonging to New Zealand rabbits subjected to ischemia and reperfusion by clamping of the extramural peri-intestinal marginal artery/vein

\begin{tabular}{ccccccc}
\hline \multirow{2}{*}{ Rabbits } & \multicolumn{5}{c}{ Score for presence of pmn in mucosa } \\
\cline { 2 - 6 } & Sham & I1H & I2H & I1H/R2H & I2H/R1H & I2H/R5H \\
\hline 1 & 0 & 1 & 4 & 3 & 3 & 3 \\
2 & 0 & 2 & 2 & 2 & 3 & 3 \\
3 & 0 & 1 & 2 & 2 & 3 \\
4 & 1 & 1 & 2 & 3 & 2 \\
5 & 0 & 2 & 2 & 3 & 3 \\
6 & 1 & 1 & $2^{\text {ac }}$ & $2^{\text {abc }}$ & & $3^{\text {bc }}$
\end{tabular}

In the same line, identical letters represent statistical equivalence and different letters represent differences between the groups. 


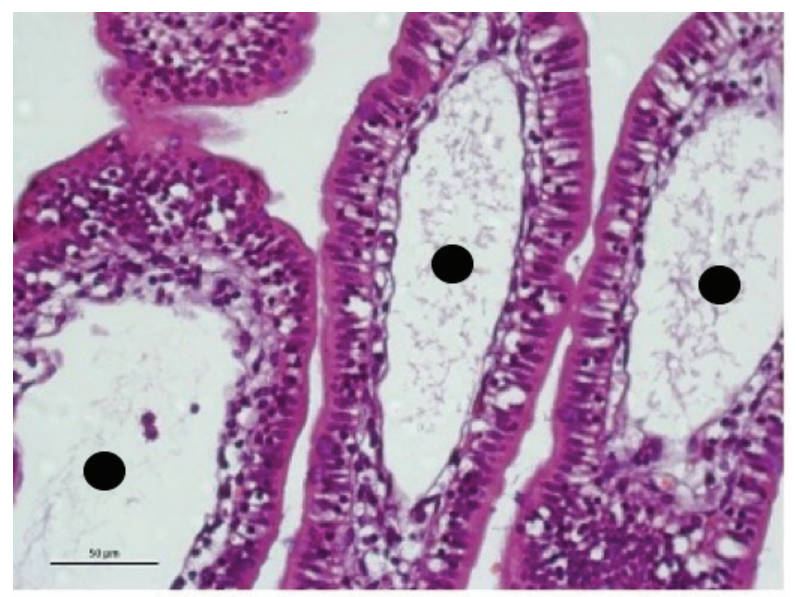

Fig.7. Photomicrography of a rabbit allocated in the I2H/R1H group displaying mild/moderate lymphatic dilation in intestinal mucosa (circle), classified as score 2. HE, 20x.

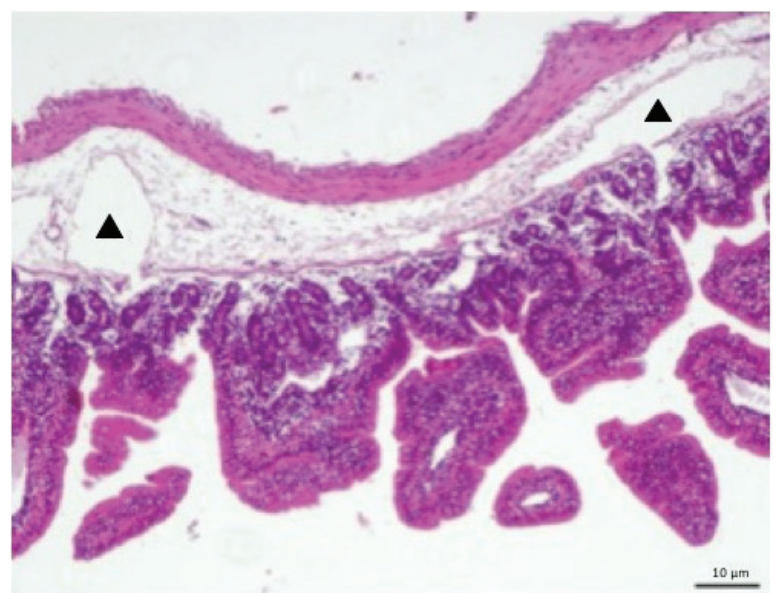

Fig.8. Photomicrography of a rabbit allocated in the I2H/R5H group displaying intense lymphatic vessel dilatation (triangle) in intestinal submucosa, classified as score 2. . HE, 10x.

Table 6. Results, in score, of the histological analysis for lymphatic dilatation in the jejunum mucosa belonging to New Zealand rabbits subjected to ischemia and reperfusion by clamping of the extramural peri-intestinal marginal artery/vein

\begin{tabular}{ccccccc}
\hline \multirow{2}{*}{ Rabbits } & \multicolumn{5}{c}{ Score for lymphatic dilatation in mucosa } \\
\cline { 2 - 6 } & Sham & I1H & I2H & I1H/R2H & I2H/R1H & I2H/R5H \\
\hline 1 & 0 & 2 & 2 & 1 & 2 & 2 \\
2 & 0 & 1 & 1 & 2 & 2 \\
3 & 0 & 1 & 1 & 1 & 2 & 2 \\
4 & 0 & 1 & 2 & 2 & 1 \\
5 & 0 & 1 & 2 & 1 & 1 \\
6 & 0 & 1 & $1^{\text {abc }}$ & $2^{\text {c }}$ & $1^{\text {abc }}$ & 2 \\
Median & $0^{\text {a }}$ & & 2 & $2^{\text {bc }}$ & $2^{\text {bc }}$
\end{tabular}

In the same line, identical letters represent statistical equivalence and different letters represent differences between the groups.

Table 7. Results, in score, of the histological analysis of submucosa edema in the jejunum submucosa belonging to New Zealand rabbits subjected to ischemia and reperfusion by clamping of the extramural peri-intestinal marginal artery/vein

\begin{tabular}{ccccccc}
\hline \multirow{2}{*}{ Rabbits } & \multicolumn{5}{c}{ Score for edema in submucosa } \\
\cline { 2 - 6 } & Sham & I1H & I2H & I1H/R2H & I2H/R1H & I2H/R5H \\
\hline 1 & 0 & 0 & 2 & 3 & 3 & 3 \\
2 & 0 & 0 & 1 & 2 & 3 & 3 \\
3 & 0 & 1 & 1 & 3 & 3 & 3 \\
4 & 0 & 0 & 2 & 3 & 4 \\
5 & 0 & 1 & 2 & 3 & 3 \\
6 & 0 & $0,5^{\text {ac }}$ & $2^{\text {abc }}$ & $3^{\text {bc }}$ & $3^{\text {b }}$ & $4^{\text {b }}$
\end{tabular}

In the same line, identical letters represent statistical equivalence and different letters represent differences between the groups.

Table 8. Results, in score, of the histological analysis of presence of polymorphonuclear cell infiltration (PMN) in the jejunum submucosa belonging to New Zealand rabbits subjected to ischemia and reperfusion by clamping of the extramural peri-intestinal marginal artery/vein

\begin{tabular}{|c|c|c|c|c|c|c|}
\hline \multirow{2}{*}{ Rabbits } & \multicolumn{6}{|c|}{ Score for presence of pmn in submucosa } \\
\hline & Sham & $\mathrm{I} 1 \mathrm{H}$ & $\mathrm{I} 2 \mathrm{H}$ & $\mathrm{I} 1 \mathrm{H} / \mathrm{R} 2 \mathrm{H}$ & $\mathrm{I} 2 \mathrm{H} / \mathrm{R} 1 \mathrm{H}$ & $\mathrm{I} 2 \mathrm{H} / \mathrm{R} 5 \mathrm{H}$ \\
\hline 1 & 0 & 0 & 2 & 3 & 2 & 3 \\
\hline 2 & 0 & 0 & 1 & 3 & 2 & 3 \\
\hline 3 & 0 & 0 & 0 & 2 & 2 & 3 \\
\hline 4 & 0 & 1 & 2 & 2 & 3 & 3 \\
\hline 5 & 0 & 1 & 1 & 2 & 2 & 2 \\
\hline 6 & 1 & 0 & 1 & 3 & 3 & 2 \\
\hline Median & $0^{\mathrm{a}}$ & $0^{\mathrm{ac}}$ & $1^{\mathrm{abc}}$ & $2,5^{b}$ & $2^{\mathrm{bc}}$ & $3^{b}$ \\
\hline
\end{tabular}

In the same line, identical letters represent statistical equivalence and different letters represent differences between the groups. 
Table 9. Results, in score, of the histological analysis of presence of lymphatic dilatation in the jejunum submucosa belonging to New Zealand rabbits subjected to ischemia and reperfusion by clamping of the extramural peri-intestinal marginal artery/vein

\begin{tabular}{ccccccc}
\hline \multirow{2}{*}{ Rabbits } & \multicolumn{5}{c}{ Score for lymphatic dilatation in submucosa } \\
\cline { 2 - 6 } & Sham & I1H & I2H & I1H/R2H & I2H/R1H & I2H/R5H \\
\hline 1 & 0 & 1 & 1 & 1 & 1 & 2 \\
2 & 0 & 1 & 1 & 2 & 2 & 2 \\
3 & 0 & 2 & 1 & 2 & 1 & 2 \\
4 & 0 & 1 & 1 & 1 & 2 \\
5 & 0 & 1 & 2 & 1 & 2 & 2 \\
6 & 0 & $1^{\text {a }}$ & $1^{\text {a }}$ & $1^{\text {b }}$ & $2^{\text {b }}$ & $2^{\text {b }}$
\end{tabular}

In the same line, identical letters represent statistical equivalence and different letters represent differences between the groups.

I1H/R2H, I2H/R1H, and I2H/R5H compared to the Sham group. The other alterations are presented in Table 9.

\section{DISCUSSION}

There are experimental studies described in literature for comprehension of the pathophysiology and the establishment of therapies for ischemia and reperfusion injuries (Yassin et al. 1997, Camargo et al. 2003, Chang et al. 2005, Ribeiro \& Yoshida 2005, Gonzalez et al. 2015, Freitas et al. 2017). However, when the pilot study of the present project was initiated, we found a discrepancy in results obtained from those described by authors using a similar methodology to the one employed. This difficulty in reproducing the data led to this study, in order to obtain an experimental model of easy reproduction, with well elucidated histopathological findings in which allows time inference for ischemia and reperfusion that entails a mild injury, yet compatible with the patient's life and with repair potential.

Several studies conducted in order to elucidate the I/R injuries, proposes the methodology of ischemic induction by occlusion of the cranial mesenteric artery (Guimarães et al. 2002, Gao et al. 2006, Jiang et al. 2011, Boybeyi et al. 2014) which leads to a generalized intestinal injury. However, when considering events occurring in the organism, it appears that some bowel diseases, primary or secondary, lead to the development of segmented intestinal lesions, which may or may not take a systemic character. Intestinal manipulation performed for model execution described by these authors cited above proved to be inefficient, often occurring handling injuries due to the organ's delicacy.

Considering these reasons, the occlusion of only one vascular branch of the extramural peri-intestinal marginal artery/vein was opted on and it was found that this proposed model was capable of causing intestinal lesions in mucosa and submucosa in rabbits, while avoiding excess bowel manipulation. Guan et al. (2009), in an experimental study of I/R intestinal injuries in mice also performed occlusion of the extramural peri-intestinal marginal artery for 15 and 50 minutes, but associated this occlusion with obstruction of the blood supply collateral to the segment. Even though using less ischemia time than that used in the present study the histopathological alterations that the authors observed were more severe, possibly due to lack of collateral vasculature.

Intestinal ischemia insult tolerance can also vary according to the different species. Experimental studies in rats and mice showed histopathological alterations in ischemic situations lasting for 30 minutes (Guimarães et al. 2002, Freitas et al. 2009a, 2009b); 45 minutes (Jiang et al. 2011.); 15 and 50 minutes (Guan et al. 2009) and 60 minutes (Boybeyi et al. 2014) whereas for dogs the ischemic time was 60 minutes (Chiu et al. 1970), for rabbits starting at 60 minutes (Gao et al. 2006) and horses starting at 70 minutes (Dabareiner et al. 2001) and 120 minutes (Pagliosa et al. 2009).

Macroscopically, a reddish aspect in serous, and well evident congested and hyperemic blood vessels well evident were noticed in group I2H group, similar to what was found by Pagliosa et al. (2009), in horses, two hours after ischemia. In the $\mathrm{I} 2 \mathrm{H} / \mathrm{R} 5 \mathrm{H}$ group it was observed, at the end of the reperfusion time, increase in serous thickness suggesting edema. This fact may be related to increased hydrostatic pressure (Vasconcelos 2002).

Histologically, the intestinal injuries that were found by histological evaluation of the mucosa were consistent with the classification proposed by Chiu et al. (1970). Applying the proposed classification, we noted that the I1H/R2H group had an injury score between 1 and 2 (median value of 2), while Gao et al. (2006) viewed massive villi destruction and exposure of mucosa's lamina propria (score 5) after clamping of the cranial mesenteric artery for one hour followed by reperfusion for two hours.

In the present study presence of significant mucosa erosion was not detected. Only in groups I1H/R2H, I2H/R1H, and $\mathrm{I} 2 \mathrm{H} / \mathrm{R} 5 \mathrm{H}$ was it possible to see some erosion sites, but considered to be incipient by the evaluator. In a study by Pagliosa et al. (2009) with equine, these same lesions were described in a more evident manner, and because of this the authors stated that the lesions started during ischemia and maintained during the reperfusion.

Furthermore, in the study by Pagliosa et al. (2009) with equine, the group in which venous occlusion was held to cause I/R damage in the jejunum, showed hemorrhage alterations and edema of mucosa and submucosa in abundance, diverging from the I1H/R2H and I2H/R1H groups which presented hemorrhage in mucosa with score $0-1$, and the group I2H/R5H with a score of 0 to 2 for mucosa and score 1 for submucosa. The occurrence of hemorrhaging can be related to increases in vascular permeability in hypoxic situations that will cause damage to the endothelial cells, either in the ischemic or reperfusion phase (Dabareiner et al. 2001, Nosál'ová et al. 2007). It is worth noting that although they are 
different animals, horses and rabbits underwent procedure for the same purpose, to induce intestinal injury.

The presence of edema and lymphatic dilatation in mucosa and submucosa were more evident in groups I1H/R2H, I2H/R1H, and $\mathrm{I} 2 \mathrm{H} / \mathrm{R} 5 \mathrm{H}$. These results suggest that reperfusion injuries increase the damage initially caused by ischemic insult and that existing vascular injuries may be exacerbated by increased capillary hydrostatic pressure and may also contribute to edema formation (Yassin et al. 1997, Carden \& Granger 2000, Camargo et al. 2003, Chang et al. 2005).

Because it is an acute injury, the presence of polymorphonuclear infiltration was observed in all groups except the Sham group. The cell type observed was the heterophil, a round cell, with a multilobulated nucleus, of acidophilus coloring and with an inflammatory function similar to the neutrophil, but presents this nomenclature particularly for rabbits. The presence of PMNs can be attributed to the fact that there is production of oxygen free radicals (OFR) during reperfusion, resulting in lipid peroxidation and cell damage which culminate with increased inflammatory response at the site of injury (Moore et al. 1995, Zhao et al. 2003, Gao et al. 2006, Jiang et al. 2011, Guzel et al. 2012). However, the incipient presence of mononuclear inflammatory process can be justified by injury's acute pattern, being insufficient time for their formation.

In no experimental group was destruction of mucosa and villi associated with strong degrees of edema, hemorrhage and presence of polymorphonuclear heterophils observed, but the I2H/R5H group had a higher injury rate, generally classified as moderate. Facts that allow us to infer that despite the injuries presented in the present study being compatible with ischemia and reperfusion injuries, the body still preserves repairing potential.

\section{CONCLUSIONS}

The proposed experimental model provided mucosa and submucosal injuries in intestinal segment, where the blood flow was occluded by clamping of the extramural peri-intestinal marginal artery/vein.

Histopathological alterations included the observation of villi denudation, edema, hemorrhage, lymphatic vessels dilatation, and the presence of inflammatory infiltrate that accentuated the longer employment of ischemia and reperfusion times.

Rabbits subjected to ischemia for two hours followed by reperfusion for five hours ( $\mathrm{I} 2 \mathrm{H} / \mathrm{R} 5 \mathrm{H})$ made up the experimental group which was easily reproducible and showed a moderate intestinal injury, however, compatible with the patient's life and with repair potential, to be employed in the next stage of the study.

Disclosure of interest.- The authors have no commercial, proprietary or financial interest in the products or companies described in this article.

Acknowledgements.- The authors thank the Conselho Nacional de Desenvolvimento Científico e Tecnológico (CNPq - Process 552488/2011-9 and 457716/2014-2) and Fundação de Amparo à Pesquisa do Espírito Santo (FAPES) for granting the fellowships and financial support that permitted us to conduct this study.

\section{REFERENCES}

Avgerinos E.D., Kostopanagiotou G., Costopanagiotou C., Kopanakis N., Andreadou I., Lekka M., Nakos G. \& Smyrniotis V. 2010. Intestinal preconditioning ameliorates ischemia-reperfusion induced acute lung injury in rats: an experimental study. J. Surg. Res. 160(2):294-301.<http:// dx.doi.org/10.1016/j.jss.2008.12.017><PMid:19439321>

Barriga A., Medrano M., De Juan J. \& Burgos J. 2013. Intravenous infusion of adult adipose tissue stem cells for repairing spinal cord ischaemic lesions. An experimental study on animals. Revta Esp. Cir. Ortop. Traumatol. 57(2):8994. <http://dx.doi.org/10.1016/j.recot.2013.01.001><PMid:23608207>

Ben D.F., Yu X.Y., Ji G.Y., Zheng D.Y., Lv K.Y., Ma B. \& Xia Z.F. 2012. TLR4 mediates lung injury and inflammation in intestinal ischemia-reperfusion. J. Surg. Res. 174(2):326-333. <http://dx.doi.org/10.1016/j.jss.2010.12.005> <PMid:21392794>

Boybeyi Ö., Gunal Y.D., Atasoy P., Kisa U. \& Aslan M.K. 2014. The effect of colchicine and low-dose methotrexate on intestinal ischemia/ reperfusion injury in an experimental model. J. Ped. Surg. 49(10):1471-1474. <http:// dx.doi.org/10.1016/j.jpedsurg.2014.01.057><PMid:25280648>

Camargo L.M., Evêncio Neto J., Freitas S.H., Simões M.J., Gomes P.O. \& Sébe A.A. 2003. Aspectos ultra-estruturais das vilosidades intestinais após o clampeamento do pedículo hepático de ratos. Acta Cir. Bras. 18(6):509-513. <http://dx.doi.org/10.1590/S0102-86502003000600005>

Carden D.L. \& Granger D.N. 2000. Pathophysiology of ischaemia-reperfusion injury. J. Pathol. 190(3):255-266. <http://dx.doi.org/10.1002/(SICI)10969896(200002)190:3<255::AID-PATH526>3.0.C0;2-6><PMid:10685060>

Chang J.X., Chen S., Ma L.P., Jiang L.Y., Chen J.W., Chang R.M., Wen L.Q., Wu W., Jiang Z.P. \& Huang Z.T. 2005. Functional and morphological changes of the gut barrier during the restitution process after hemorrhagic shock. World J. Gastroenterol. 11(35):5485-5491. <http://dx.doi.org/10.3748/ wjg.v11.i35.5485><PMid:16222741>

Chiu C.J., Scott H.J. \& Gurd F.N. 1970. Intestinal mucosal lesion in lowflow states. II: the protective effect of intraluminal glucose as energy substrate. Arch. Surg. 101(4):484-488. <http://dx.doi.org/10.1001/ archsurg.1970.01340280036010 > <PMid:5311679>

Dabareiner R.M., Sullins K.E., White N.A. \& Snyder J.R. 2001. Serosal injury in the equine jejunum and ascending colon after ischemia reperfusion or intraluminal distention and decompression. Vet. Surg. 30(2):114-125. <http://dx.doi.org/10.1053/jvet.2001.21393><PMid:11230765>

Freitas S.H., Evencio Neto J., Doria R.G.S., Mendonca F.S., Simões M.J., Camargo L.M. \& Sébe A.A. 2009a. Aspectos macroscópicos, morfológicos e morfométricos do baço de ratos após o clampeamento total do pedículo hepático. Ciênc. Anim. Bras. 10:1218-1226.

Freitas S.H., Evencio Neto J., Doria R.G.S., Mendonca F.S., Simões M.J., Camargo L.M. \& Sébe A.A. 2009b. Aspectos morfológicos, morfométricos e ultraestruturais de baços de ratos após o clampeamento total do pedículo hepático. Arq. Bras. Med. Vet. Zootec. 61(6):1314-1321. <http://dx.doi. org/10.1590/S0102-09352009000600010>

Freitas S.H., Dória R.G.S., Bueno R.S., Rocha W.B., Filho J.R.E., Moraes J.R.E., Vidane A.S. \& Ambrósio C.E. 2017. Evaluation of potential changes in liver and lung tissue of rats in an ischemia-reperfusion injury model (modified pringle maneuver). Plos One 12(6):e0178665. <http://dx.doi.org/10.1371/ journal.pone.0178665><PMid:28604841>

Gao C., Chai W., Xu L., Zhang G., Zhang H., Han L. \& Sun X. 2006. Protective effects of hyperoxygenated solution preconditioning on intestinal ischemiareperfusion injury in rabbits. J. Surg. Res. 135(2):268-274. <http://dx.doi. org/10.1016/j.jss.2006.03.019><PMid:16863653>

Gonçalves E.S., Rabelo C.M., Prado Neto A.X., Garcia J.H., Guimarães S.B. \& Vasconcelos P.R. 2011. Effect of short-term ornithine alpha-ketoglutarate pretreatment on intestinal ischemia-reperfusion in rats. Acta Cir. Bras. 26(Suppl.1):2-7.<http://dx.doi.org/10.1590/S0102-86502011000700002> $<$ PMid:21971649>

Gonzalez L.M., Moeser A.J. \& Blikslager A.T. 2015. Animal models of ischemiareperfusion-induced intestinal injury: progress and promise for translational research. Am. J. Physiology-Gastrointestinal Liver Physiol. 308(2):63-75. <http://dx.doi.org/10.1152/ajpgi.00112.2013> 
Guan Y., Wottell R.T., Pritts T.A. \& Montresel M.H. 2009. Intestinal ischemiareperfusion injury: reversible and irreversible damage imaged in vivo. Am. J. Physiology-Gastrointestinal Liver Physiol. 297(1):187-196. <http:// dx.doi.org/10.1152/ajpgi.90595.2008>

Guimarães F.A., Taha M.O., Simoes M.J. \& Fagundes D.J. 2002. Ischemiareperfusion of the small intestine and hyperbaric oxygen treatment: a morphologic study in rats. Transplantation Proc. 34(3):977-979. <http:// dx.doi.org/10.1016/S0041-1345(02)02726-4> <PMid:12034268>

Guzel A., Kanter M., Guzel A., Pergel A. \& Erboga M. 2012. Anti-inflammatory and antioxidant effects of infliximab on acute lung injury in a rat model of intestinal ischemia/reperfusion. J. Mol. Histol. 43(3):361-369. <http:// dx.doi.org/10.1007/s10735-012-9396-0> <PMid:22389028>

Jiang H., Qu L., Li Y., Gu L., Shi Y., Zhang J., Zhu W. \& Li J. 2011. Bone marrow mesenchymal stem cells reduce intestinal ischemia/reperfusion injuries in rats. J. Surg. Res. 168(1):127-134. <http://dx.doi.org/10.1016/j. jss.2009.07.035> <PMid:19932900>

Kostopanagiotou G., Avgerinos E., Costopanagiotou C., Arkadopoulos N., Andreadou I., Diamantopoulou K., Lekka M., Smyrniotis V. \& Nakos G. 2007. Acute lung injury in a rat model of intestinal Ischemia-Reperfusion: the potential time depended role of phospholipases A2. J. Surg. Res. 147(1):108116. <http://dx.doi.org/10.1016/j.jss.2007.07.023><PMid:17981297>

Medeiros A.D.C., Torres M.L., Sá C.D.V., Jácome D.T. \& Rêgo A.C.M. 2013. Ischemic preconditioning in different times and its effect on bacterial translocation induced by intestinal ischemia and reperfusion in rats. Revta Col. Bras. Cir. 40(1):55-59. <http://dx.doi.org/10.1590/S0100-69912013000100010> $<$ PMid:23538540>

Moore R.M., Muir W.W. \& Granger D.N. 1995. Mechanisms of gastrointestinal ischemia-reperfusion injury and potential therapeutic interventions: a review and its implications in the horse. J. Vet. Int. Med. 9(3):115-132. <http://dx.doi.org/10.1111/j.1939-1676.1995.tb03285.x><PMid:7674213>

Nosál’ová V., Navarova J., Mihalova D. \& Sotnikova R. 2007. Mesenteric ischemia/reperfusion-induced intestinal and vascular damage: Effect of stobadine. Methods Findings Exp. Clin. Pharmacol. 29(1):39-45. <http:// dx.doi.org/10.1358/mf.2007.29.1.1063495><PMid:17344943>

Pagliosa G.M., Alves G.E.S., Faleiros R.R., Matos J.R.T.D., Torres M.B., Mendes H.M.F. \& Costa R.S. 2009. Use of glutamine to treatment of ischemia and reperfusion lesions in equine jejune. Pesq. Vet. Bras. 29:246-252. <http:// dx.doi.org/10.1590/S0100-736X2009000300010>

Ribeiro M.E. \& Yoshida W.B. 2005. Lesões intestinais decorrentes de isquemia e reperfusão: fisiopatologia e modelos experimentais. J. Vasc. Bras. 4:183-194.

Ritz J.P., Germer C.T. \& Buhr H.J. 2005. Prognostic factors for mesenteric infarction: multivariate analysis of 187 patients with regard to patient age. Ann. Vasc. Surg. 19(3):328-334. <http://dx.doi.org/10.1007/s10016005-0005-5> <PMid:15818455>

Santos C.H., Gomes O.M., Pontes J.C., Miiji L.N. \& Bispo M.A. 2008. The ischemic preconditioning and postconditioning effect on the intestinal mucosa of rats undergoing mesenteric ischemia/reperfusion procedure. Acta Cir. Bras. 23(1):22-28. <http://dx.doi.org/10.1590/S0102-86502008000100005> $<$ PMid:18278389>

Tang Z.H., Qiang J.W., Feng X.Y., Li R.K., Sun R.X. \& Ye X.G. 2010. Acute mesenteric ischemia induced by ligation of porcine superior mesenteric vein: multidetector CT evaluations. Acad. Radiol. 17(9):1146-1152. <http:// dx.doi.org/10.1016/j.acra.2010.04.014> <PMid:20646939>

Vasconcelos A.C. 2002. Alterações circulatórias: trombose, embolia, isquemia, lesões de reperfusão e infarto. ICB-UFMG, Belo Horizonte. (Notas de aula, Curso de Patologia Geral)

Yassin M.M., Barros D’sa A.A., Parks T.G., McCaigue M.D., Leggett P., Halliday M.I. \& Rowlands B.J. 1997. Lower limb ischaemia-reperfusion injury alters gastrointestinal structure and function. Brit. J. Surg. 84(10):1425-1429. <http://dx.doi.org/10.1002/bjs.1800841023> <PMid:9361604>

Yurdakan G., Tekin I.O., Comert M., Acikgoz S. \& Sipahi E.Y. 2012. The presence of oxidized low-density lipoprotein and inducible nitric oxide synthase expression in renal damage after intestinal ischemia reperfusion. Kaohsiung J. Med.Sci. 28(1):16-22. <http://dx.doi.org/10.1016/j.kjms.2011.06.030> <PMid:22226057>

Zhao Z.Q., Corvera J.S., Halkos M.E., Kerendi F., Wang N.P., Guyton R.A. \& VintenJohansen J. 2003. Inhibition of myocardial injury by ischemic postconditioning during reperfusion: comparison with ischemic preconditioning. Am. J. Physiol. Heart Circulatory Physiol. 285(2):H579-H588. <http://dx.doi. org/10.1152/ajpheart.01064.2002> <PMid:12860564> 